Rare ventures:

New business models

in drug development

for orphan diseases

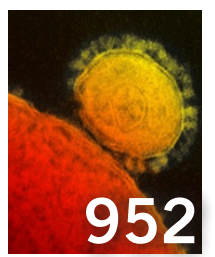

Oh MERS-y:

Animal models sought

for Middle East

respiratory syndrome

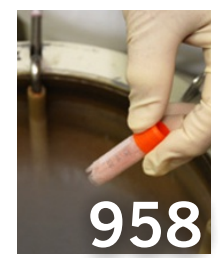

A fertile future:

Scientists strive to

restore fertility in

young cancer survivors

\title{
Myriad sues developers of competing breast cancer tests
}

After a four-year legal battle that wound its way through the district courts of New York, the federal appeals court in Washington, DC, and finally to the bench of the US Supreme Court, the landmark case challenging the legality of patents on human genes is finally over. But just as the dust was settling from the Supreme Court's decision that human genes are "products of nature," and therefore not patentable, three new fights are already brewing.

The Supreme Court invalidated Myriad Genetics's patents on the human breast cancer genes BRCA1 and BRCA2 in a 5-4 decision on 13 June, and expectations were great that the "victory for genes," as this publication hailed it (Nat. Med. 19, 792, 2013), would bring freedom and equality to clinicians, researchers and life sciences companies. Yet "we've woken up with a hangover," says Hans Sauer, deputy general counsel for the Washington, DCbased Biotechnology Industry Organization. The most immediate result of the ruling has been "boring litigation between competing companies," he says. "It's a bit of a letdown."

Within days of the ruling, two companies, Ambry Genetics and Gene By Gene, began offering significantly less expensive $B R C A$ genetic tests to patients. In response, Myriad, along with its patent co-owners, which include two universities in the US and two Canadian organizations with academic ties, sued both companies for patent violation. The lawsuits, filed last month in a federal court in Utah, point to ten other patents covering methods of testing and synthetic primers, probes and arrays made of laboratory-synthesized DNA, or CDNA, which the Supreme Court ruled is patentable. Myriad, which is headquartered in Salt Lake City, Utah, has also requested preliminary injunctions to stop the two companies from selling competing tests.

Ron Rogers, a spokesperson for Myriad, told Nature Medicine that the lawsuits are "ordinary classic patent cases" of one competitor suing another. "We're pretty confident in our position that they are in fact infringing on our patents," he says.

In each case, the burden is now on Ambry and Gene By Gene to prove they are not

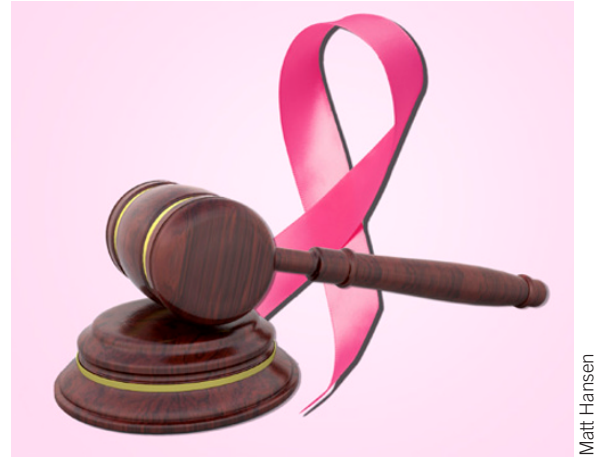

Sequence of events: BRCA suits crop up.

using Myriad's patented technologies. And based on publicly available information on the company's websites, both companies may indeed be using the same cDNA primers and probes that Myriad has patented, says Jacob Sherkow, a patent scholar at Stanford Law School's Center for Law and the Biosciences in California who has reviewed the cases. As such, "Myriad may win on some of its claims," he suggests.

Gene By Gene, which is based in Texas, declined to comment on the lawsuit, but Ardy Arianpour, senior vice president of business development at California-based Ambry, says that Ambry's test is "legitimate competition," and that the company will "vigorously defend" itself in court.

\section{From genes to cells}

A third legal action made in the wake of the recent gene patenting decision comes from a California-based advocacy group called Consumer Watchdog and the Public Patent Foundation (PUBPAT), the New York-based nonprofit that together with the American Civil Liberties Union took Myriad to the Supreme Court. Consumer Watchdog and PUBPAT asked the US federal appeals court on 2 July to revoke a patent held by the Wisconsin Alumni Research Foundation (WARF) that covers in vitro cultures of human embryonic stem cells.

The two groups had first challenged the patent's validity back in 2006 . They succeeded in getting it invalidated in 2010 after some back-and-forth decisions from the US Patent and Trademark Office, during which WARF narrowed its claims from all human pluripotent stem cells, which would have covered induced pluripotent stem cells, to only those derived from preimplantation embryos. But the patent office ruled in January of this year to uphold WARF's more restricted patent. This set the stage for Consumer Watchdog and PUBPAT to appeal once again.

The timing is "perfect," says Jeanne Loring, director of the Center for Regenerative Medicine at the Scripps Research Institute in La Jolla, California, because the groups can now invoke the 'product of nature' exception cited in the Supreme Court's BRCA decision. Loring has been involved in trying to revoke the WARF patents since 2004 and will testify as an expert witness for the upcoming appeal. Now, she says, there's "an opportunity to try to expand the Myriad ruling in general to things that occur in nature."

Hank Greely, director of Stanford's Center for Law and the Biosciences, finds the groups' new 'product of nature' claim weak. "It seems to me quite a stretch that if you've figured out a way to take inner cell mass cells from a blastocyst and keep them growing indefinitely in vitro without spontaneously differentiating into other cell types, that you can call that a product of nature." But Dan Ravicher, founder and executive director of PUBPAT, disputes Greely's reasoning. "That's exactly what Myriad argued in the [Supreme Court] case-that isolated DNA taken out of the body is vastly different from DNA in the body," he says. "I'm not saying that's a frivolous argument, but I don't think it's a winner." WARF is currently reviewing the case and declined to comment for this story.

These three cases are the first-but surely not the last-to follow the Supreme Court's Myriad decision, notes Sherkow. And many issues remains unclear, such as whether isolated and purified biologic products, including moneymaking antibody drugs, are patentable. "This issue is going to come up sooner rather than later," Sherkow says. "I can certainly see more litigation coming in this space."

Megan Scudellari 